\title{
On the Users' Intention to Adopt Mobile Banking: The Role of Subject Norm
}

\author{
Chen Xinhui ${ }^{1,2}$, Ji Xiangxiang ${ }^{1}$, Zhang Xinrui ${ }^{1}$ \\ ${ }^{1}$ School of Economics and Management, North China University of Technology, Beijing, PR China \\ ${ }^{2}$ School of Business and Management, North China Electric Power University, Beijing, PR China
}

\section{Email address:}

55618975@qq.com (Chen Xinhui), 149824974@qq.com (Ji Xiangxiang), ameliabj@163.com (Zhang Xinrui)

\section{To cite this article:}

Chen Xinhui, Ji Xiangxiang, Zhang Xinrui. On the Users' Intention to Adopt Mobile Banking: The Role of Subject Norm. Science Journal of Business and Management. Vol. 3, No. 6, 2015, pp. 235-241. doi: 10.11648/j.sjbm.20150306.14

\begin{abstract}
Mobile banking has become a new field that bank industry because of its advantages of convenience, openness, real-time as a new e-commerce bank, promoting the users intention is one of the issues of development. First of all, the paper establishes the relationship model that affects the mobile bank user's intention on the base of Technology Acceptance Model and Theory of Planned behavior. Secondly, the paper carries out questionnaire survey on Beijing mobile bank users and gets 136 effective samples. In the end, the paper conducts empirical research using structural equation model and gets a conclusion that perceived usefulness and perceived risk have significant impact on users intention, especially subjective norms not only has a direct impact but also an indirect effect on user intention. The results indicate subject norm has significant impact on user intention and Perceived Ease of Use has significant impact on user intention by the mediating of subject norm. Therefore, strengthening the safety and external publicity of mobile phone bank is the key to win the customers.
\end{abstract}

Keywords: Mobile Banking, Structural Equation Model, User's Intention

\section{Introduction}

Mobile banking can also be called mobile banking service, which is the abbreviation of using mobile network and terminal to handle relevant bank business. As a completely new service of combining money's computerizing and mobile communication, mobile bank business can not only enable people to deal with a variety of financial business at anytime and anywhere, but also greatly enriched the connotation of electronic banking service and enable banks to provide users with the traditional and innovative services in convenient, efficient and safe way.

Mobile banking in China started in the early 21 st century, with the gradual maturity of $3 \mathrm{G}$ technology and rapid development of $4 \mathrm{G}$ technology, Mobile banking more highlights the advantages of convenience, openness and real-time. The industry develops very fast and user scale continues to increase. According to 《2014 China mobile banking market research report $\rangle$, the total number of the mobile banking customers of China's large and medium-sized listed Banks had broke through 400 million, and $48 \%$ of the users rarely use mobile banking service [1]. Compared with 1.3 billion mobile phone users in China, the proportion of opening mobile banking service is still not high; user's intention is not strong. Promoting the users intention is an important issue that banks in our country have faced. This paper will view mobile banking as a new technology system to explore the relevant factors that affects mobile bank user's intention and provide targeted advice for banks to carry out mobile banking service marketing decision, through the questionnaire survey and randomly selecting mobile banking users as the investigation object.

\section{Background of Theory and Research Hypothesis}

\subsection{Background of Theory}

We view mobile banking as an information technology system, and the most authoritative result about information technology system user adoption issue is the Technology Accepted Model put forward by Davis (1989) [2]. The model establishes the theoretical relationship among consumer perception, attitude, intention and behavior. The model contains two main decisive factors: 1. Perceived Usefulness. It reflects the degree of the improvement to one's work 
performance if a person considers using a system. 2. Perceived Ease of Use. It reflects the degree of ease if a person use a system. Many scholars at home and abroad use the model to study the influence factors of mobile banking users intention. Such as Namho Chung (2010) proved that the perceived usefulness and perceived ease of use have influence on users intention, and he also found that mobile banking technical support also have an impact on uses attention. [3] Kleijnen (2004) adds three factors on the basis of Davis model, namely the cognitive of system quality, economic cost and social impact. The results show that users intention is also significantly affected by these three factors [4]. In recent years, domestic scholars also have begun to use the technology accepted model and Chinese users samples for empirical research. The results of the study are basically identical with foreign scholars. (Luo Xuan, 2013; Zhao Qianru, 2010).

But we believe that the technology accepted model is mainly from the perspective of user perception and it overlooks some influence factors of behavior intention. If we simply use the technology accepted model in the research, systematicness of the study will be discounted. Therefore, this study will introduce another classic theory, namely Planned Behavior Theory (Theory of Planned Behavior, TPB). Theory of planned behavior is put forward by Ajzen (1985). Planned behavior theory can help us understand how people change their behavior patterns. TPB views our individual behavior intention as the outcome of combined action of three factors, namely attitude, subjective norm and perceived behavior control [5]. Attitude is determined by the perceived ease of use and perceived usefulness; Subjective norms refers to the quantity of the effects about those individuals or groups that have influence on individual behavior decision-making, whether to decide to take a particular behavior influence; And perceived behavior control refers to the difficulty degree of the personal resources, it reflects the individuals for the perception of some perceived behavior control. This article is based on technology accepted model and the theory of planned behavior. There are six factors that influence the mobile banking user intention, namely perceived usefulness, perceived ease of use, perceived risk, perceived cost and perceived equipment performance and subjective norm.

\subsection{Research Hypothesis}

The emergence of mobile banking not only brings great convenience to users, but also reduces the operating cost for banks and gives banks an opportunity of taking advantage of personalized service to attract customers. And the premise of using this new type of electronic banking services to attract customers is the real master of the decisive factors of mobile banking users intention. Users' intention reflects users' aspiration to register mobile banking service, it is a necessary condition before a user action and it is verified in many researches Therefore, this research will put mobile banking users' intention (UI) as a dependent variable and only consider its front influence factors.

1) Perceived Usefulness (PU)

Perceived usefulness refers to users' perception of the convenience of living that mobile banking service has brought and the improvement of working efficiency. Perceived usefulness is one of the basic factors of TAM model. At the same time in the existing study, its impact on users intention is also proved by Lopes (2008) and other scholars [6]. Chinese scholar Zhong Xiaona (2005) verified that the perceived usefulness has positive effects on users' intention [7]. Hsu and $\mathrm{Lu}$ (2004) proved that perceived usefulness in their research is an important factor of users' intention [8]. A recent industry survey results also show that $70.8 \%$ of the users for mobile banking service is because of its convenience and quickness [1]. Therefore, this paper puts forward the following hypothesis:

H1: Perceived usefulness has significant and positive effects on mobile banking users intention.

2) Perceived Ease of Use (PEU)

Perceived ease of use refers to users' perception of the mobile banking registration, operation and use. In the TAM model, perceived ease of use positively influence perceived usefulness, but does not directly affect the users' intention. Guo Xunhua (2009) also confirmed that the perceived ease of use has a significant effect on perceived usefulness [9]. Liu (2010) argued that perceived ease of use of mobile banking users will not dramatically influence users' intention [10]. This paper argues that if mobile banking use is very convenient, it will let users easily feel the effect that mobile banking service has brought. So, this paper puts forward the following hypothesis:

$\mathrm{H} 2$ : Perceived ease of use has a positive and significant influence on perceived usefulness.

3) Perceived Risk (PR)

Perceived risk refers to users' uncertain perception of expected results in the use of mobile banking service. Cheng Hua (2003) argues that security is a very important factor of uses' adoption of new financial service [11]. If the user thinks that mobile banking services are safe, they will tend to use this service. Pavlou (2003) also proves that the perceived risk has negative influence on perceived usefulness [12]. Mobile banking users' perceived risk is lower, the stronger is its perceived usefulness. A recent industry survey showed that when $55.8 \%$ of users use mobile banking, the most concern is the safety of mobile banking [1]. Based on this, this paper put forward the assumptions:

H3: Perceived risk has a reverse influence on individuals' intention to use.

H4: Perceived risk has a reverse influence on perceived usefulness.

\section{4) Perceived Cost (PC)}

Perceived cost refers to users' perception of the cost they paid after using mobile banking services, including the mobile phone traffic fees, bank service charge and time cost. Wei (2009) argues that perceived cost is one of the important factors that influence the mobile banking users intention [13]. In many relevant financial services or user adoption of wireless value-added services study, scholars view economic costs as a very important factor to examine [14], proved that the economic cost is the relative advantage of an information 
technology system and is one of the decisive factors of affecting user adoption. Dai and Palvia (2008) found in the comparative study on the mobile commerce adoption factors of China and the United States, perceived cost is the common factors that influence users' intention of two countries [15]. We believe that mobile banking is also a typical application of mobile electronic commerce. Therefore, this article puts forward the assumption:

H5: Perceived cost has a reverse effect on mobile banking users' intention.

5) Perceived Equipment Performance (PEP)

Perceived equipment performance refers to the perception of mobile banking service terminal performance and the availability of the wireless signal and quality. China's current mobile banking service is mainly provided by WAP mode and client mode, for mobile phone users, mobile phone function and the quality of wireless networks need to be considered firstly. Therefore, the quality of mobile phone and wireless network performance are the technical support of using mobile banking service for users. We believe that if the phone performance is very poor, they will take a long time to use, consume a lot of traffic, increase the cost and risk, which affect the users' intention. Therefore, this article puts forward assumption:

H6: Perceived equipment performance has positive influence on mobile banking users intention.

6) Subjective Norms (SN)
Subjective norms popularly means individual behavior is influenced by the surrounding environment, such as family and friends, colleagues and media advertising will affect the individual's intention to use mobile phones. These are the embodiment of the subjective norm action [16]. Kaooos and Rivardl (2008) in their study show that in the mobile e-commerce influence factors, the subjective norm has a significant positive effect on users' intention [17]. If a user sees the person who has important influence on he or she are using mobile banking and has the joyful use experience, then it will influence his prior judgment of ease of use and usefulness of mobile phone banking, and at the same time the fear of risk will be reduced, so as to enhance his or her mobile banking using intention. As a result, the user subjective norms has a direct impact on using intention, perceived usefulness, perceived ease of use and perceived risk. So this article puts forward the following hypothesis:

H7: Subjective standard has a direct impact on mobile banking users intention.

H8: Subjective norm has a direct effect on users perceived usefulness.

H9: subjective norm has a direct impact on the users' perceived ease of use.

H10: Subjective norm has a direct influence on users' perceived risk.

According to the above assumptions, this paper constructed the following conceptual model (figure 1).

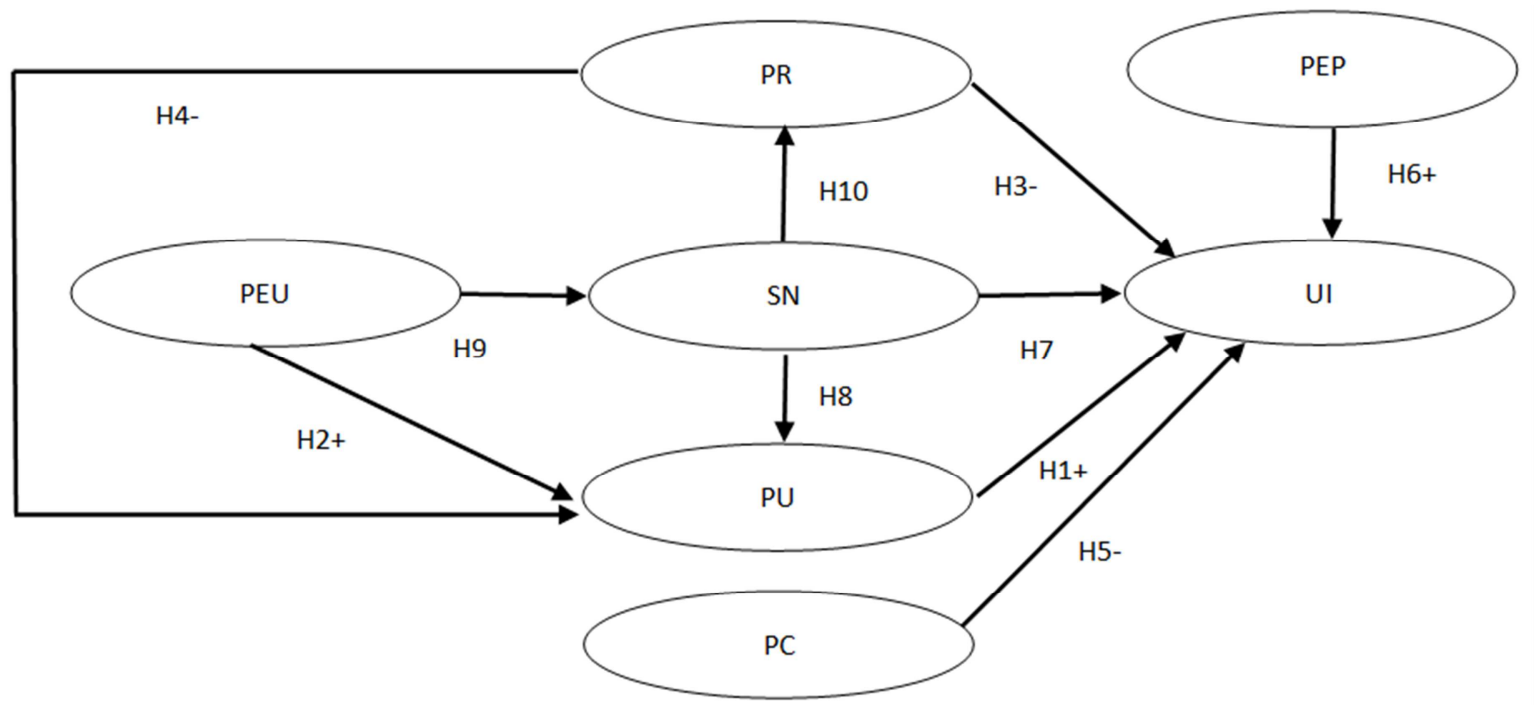

Fig. 1. The conceptual model.

\section{Research Methods}

\subsection{Scale Design and Data Collection}

In reference to the use foreign mobile e-commerce will related scale, on the basis of combining the feature of mobile banking the survey questionnaire is designed. In the concrete design, the scale is from the seven dimensions "subjective norms", "perceived usefulness" and "perceived ease of use" and "perceived equipment performance", "perceived risk" and "perceived cost" and "use"to design 21 item. The object of investigation answers the items by filling a Likert7 level scale.The greater the number represents, the higher the proving degree is. The meaning of 1-7 points respectively represents completely disagree, disagree, more disagree, neutral, more agree, agree and completely agree.

Between November - December 2014, we take the random interviews for on-the-job MBA students in colleges and universities and district residents around schools, the participants' age is between 25 to 35 years old.They are belong to the high percentage of using mobile banking and are representative; At the same time, women occupy $48 \%$, men 
for $52 \%$. They are basically flat; $90 \%$ of the researcher's education level is undergraduate and postgraduate, in accordance with the target user group that the current mobile phone banking services for. Therefore, this research has full rationality of the sample structure. Out 140 questionnaires,
136 copies of valid questionnaires, the questionnaires recovery rates are $97.14 \%$, valid questionnaire rate is $100 \%$. At the same time, the interviewers are staffs from all walks of life. The sample is representative (table 1).

Tab. 1. The sample characteristics.

\begin{tabular}{|c|c|c|c|c|c|c|c|}
\hline Gender & Percent & Age & Percent & Occupation & Percent & education degree & Percent \\
\hline Male & 52 & $20-$ & 0.74 & Student & 60.29 & High school- & 2.94 \\
\hline \multirow[t]{3}{*}{ Female } & 48 & $21-30$ & 69.85 & Enterprise personnel & 25.74 & College & 8.09 \\
\hline & & $40+$ & 0 & Doctor & 2.94 & Graduate + & 41.18 \\
\hline & & & & Civil servant & 8.82 & & \\
\hline
\end{tabular}

\subsection{Reliability and Validity of Scale}

\subsubsection{Reliability Analysis}

Before the path analysis, we use Cronbach alpha coefficient to examine internal consistency reliability [18]. In social sciences research, it is generally believed that the alpha coefficient is greater than 0.6, which indicates that the reliability is reliable. We use SPSS19.0 statistical software to calculate the reliability of the concept scale, and find that the alpha coefficient of perceived risk is 0.487 , which shows that the reliability is not reliable. Upon examination, the third item of the "perceived risk" dimensions has certain defects. We decided to remove the three projects and again calculate the reliability coefficient. Test results show that the perceived costs of alpha coefficient is 0.604 . Compared with other variable, the coefficient is low. This probably is due to the low respondents' attention to the cost. The other alpha coefficient is above 0.8 . It reaches the internal consistency significant level (Table 2).

Tab. 2. The reliability analysis of scale items.

\begin{tabular}{ll|l|l}
\hline Factor & Item number & $\boldsymbol{\alpha}$ & Item problem \\
\hline SN & 3 & 0.833 & \\
PU & 3 & 0.949 & \\
PEU & 3 & 0.865 & \\
PEP & 3 & 0.867 & Delete item 3: I think it is \\
PR & 3 & 0.952 & safe to use mobile bank \\
PC & 3 & 0.604 & \\
UI & 3 & 0.923 & \\
\hline
\end{tabular}

\subsubsection{Validity Analysis}

We use the average extraction of variance that is AVE to distinguish convergent validity and differentiate validity ${ }^{[19]}$ : If all the factors of AVE are greater than 0.5 (the square root of AVE is greater than 0.707 ), the convergent validity of the model is better; If all the factors of the square root of AVE is greater than the correlation coefficient between the various factors, the distinguish validity of the model is better. Table 3 lists the correlation coefficient between different affecting factors, and the square root of AVE is shown on the diagonal, as the chart shows, the square root of AVE is greater than 0.707 and is greater than all factors. From the judgment, the validity of this model is satisfactory.
Tab. 3. AVE and correlation of variables.

\begin{tabular}{llllllll}
\hline & SN & PU & PEU & PEP & PR & PC & UI \\
\hline SN & 0.801 & & & & & & \\
PU & 0.710 & 0.928 & & & & & \\
PEU & 0.602 & 0.714 & 0.893 & & & & \\
PEP & 0.593 & 0.704 & 0.738 & 0.849 & & & \\
PR & 0.030 & 0.092 & 0.125 & 0.242 & 0.787 & & \\
PC & 0.597 & 0.711 & 0.625 & 0.659 & 0.469 & 0.893 & \\
UI & 0.625 & 0.761 & 0.772 & 0.638 & -0.16 & 0.776 & 0.894 \\
\hline
\end{tabular}

\section{Data Analysis and Results}

This study uses the structural equation model to make a hypothesis test, to estimate the significance of path coefficients. Finally, the path coefficients and $\mathrm{P}$ values are attained, as the following table 4 .

Tab. 4. The path coefficient of the model and the P value.

\begin{tabular}{lll}
\hline Hypothesis & Path coefficient & The value of $\mathbf{P}$ \\
\hline $\mathrm{H} 1+: \mathrm{PU} \rightarrow \mathrm{UI}$ & 0.755 & $* * *$ \\
$\mathrm{H} 2+: \mathrm{PEU} \rightarrow \mathrm{PU}$ & 0.505 & $* * *$ \\
$\mathrm{H} 3-: \mathrm{PR} \rightarrow \mathrm{UI}$ & -0.170 & $* * *$ \\
$\mathrm{H} 5-: \mathrm{PC} \rightarrow \mathrm{UI}$ & 0.406 & $*$ \\
$\mathrm{H} 7: \mathrm{SN} \rightarrow \mathrm{UI}$ & 0.396 & $*$ \\
$\mathrm{H} 8: \mathrm{SN} \rightarrow \mathrm{PU}$ & 0.449 & $* * *$ \\
$\mathrm{H} 9: \mathrm{SN} \rightarrow \mathrm{PEU}$ & 0.712 & $* * *$ \\
$\mathrm{H} 10: \mathrm{SN} \rightarrow \mathrm{PR}$ & 0.415 & $*$ \\
\hline
\end{tabular}

$* \mathrm{P}<0.05 ; * * * \mathrm{P}<0.001$

We can learn path coefficient from table 4 , the assumptions 1 to 10 are significantly founding, and the perceived usefulness has significant impact on the path coefficient $(\beta=$ $0.755, \mathrm{p}<0.001$ ) of mobile banking users' use intention, support hypothesis 1; Perceived ease of use has significant impact on the path $\operatorname{coefficient}(\beta=0.505, \mathrm{p}<0.001)$ of perceived usefulness, support hypothesis 2 ; The perceived risk has significant impact on the path coefficient $(\beta=0.17, \mathrm{p}$ $<0.001$ ) of mobile banking users' use intention, support hypothesis 3; Perceived costs has significant impact on the path coefficient $(\beta=0.406, p<0.05)$ of mobile banking users' use intention, support hypothesis 5; Subjective norms has significant impact on the path coefficient $(\beta=0.396, p<0.05)$ of mobile banking users' use intention, support hypothesis 7; 
Subjective norms has significant impact on of the path coefficient $(\beta=0.449, \mathrm{p}<0.001)$ of perceived usefulness, support hypothesis 8 ; Subjective norms has significant impact on of the path coefficient $(\beta=0.712, p<0.001)$ of perceived ease of use, support hypothesis 9; Subjective norms has significant impact on the path coefficient $(\beta=0.415, \mathrm{p}<0.05)$ of the perceived risk, support hypothesis 10 . At the same time, the path coefficient of subjective norms through perceived risk is $\beta=0.325$, the impact is significant; the path coefficient of subjective norms through the perceived usefulness is $\beta=$ 0.528 , the impact is also significant. Figure 2 and table 5 are the final hypothesis testing results.

Subjective norms has significant impact on the path coefficient $(\beta=0.396, p<0.05)$ of mobile banking users' use intention; Perceived ease of use has significant impact on the path coefficient $(\beta=0.282, p<0.001)$ on user intention by mediating of Subject Norm. In addition, Subject Norm has indirect significant impact on user intention by perceived risk $(\beta=0.071, \mathrm{p}<0.001)$ and by perceived usefulness $(\beta=0.339, \mathrm{p}<0.001)$.

Tab. 5. The results of hypothesis testing.

\begin{tabular}{|c|c|c|c|}
\hline Hypothesis & $\begin{array}{l}\text { The inspection } \\
\text { result }\end{array}$ & Hypothesis & $\begin{array}{l}\text { The inspection } \\
\text { result }\end{array}$ \\
\hline $\mathrm{H} 1+: \quad \mathrm{PU} \rightarrow \mathrm{UI}$ & $\begin{array}{l}\text { Accept the } \\
\text { inspection }\end{array}$ & $\mathrm{H6}+: \mathrm{PEP} \rightarrow \mathrm{UI}$ & $\begin{array}{l}\text { Reject the } \\
\text { hypothesis }\end{array}$ \\
\hline $\mathrm{H} 2+: \quad \mathrm{PEU} \rightarrow \mathrm{PU}$ & $\begin{array}{l}\text { Accept the } \\
\text { inspection }\end{array}$ & $\mathrm{H} 7: \mathrm{SN} \rightarrow \mathrm{UI}$ & $\begin{array}{l}\text { Accept the } \\
\text { inspection }\end{array}$ \\
\hline $\mathrm{H} 3-: \mathrm{PR} \rightarrow \mathrm{UI}$ & $\begin{array}{l}\text { Accept the } \\
\text { inspection }\end{array}$ & $\mathrm{H} 8: \mathrm{SN} \rightarrow \mathrm{PU}$ & $\begin{array}{l}\text { Accept the } \\
\text { inspection }\end{array}$ \\
\hline $\mathrm{H} 4-: \mathrm{PR} \rightarrow \mathrm{PU}$ & $\begin{array}{l}\text { Reject the } \\
\text { hypothesis }\end{array}$ & $\mathrm{H} 9: \mathrm{SN} \rightarrow \mathrm{PEU}$ & $\begin{array}{l}\text { Accept the } \\
\text { inspection }\end{array}$ \\
\hline H5-: PC $\rightarrow \mathrm{UI}$ & $\begin{array}{l}\text { Accept the } \\
\text { inspection }\end{array}$ & $\mathrm{H} 10: \mathrm{SN} \rightarrow \mathrm{PR}$ & $\begin{array}{l}\text { Accept the } \\
\text { inspection }\end{array}$ \\
\hline
\end{tabular}

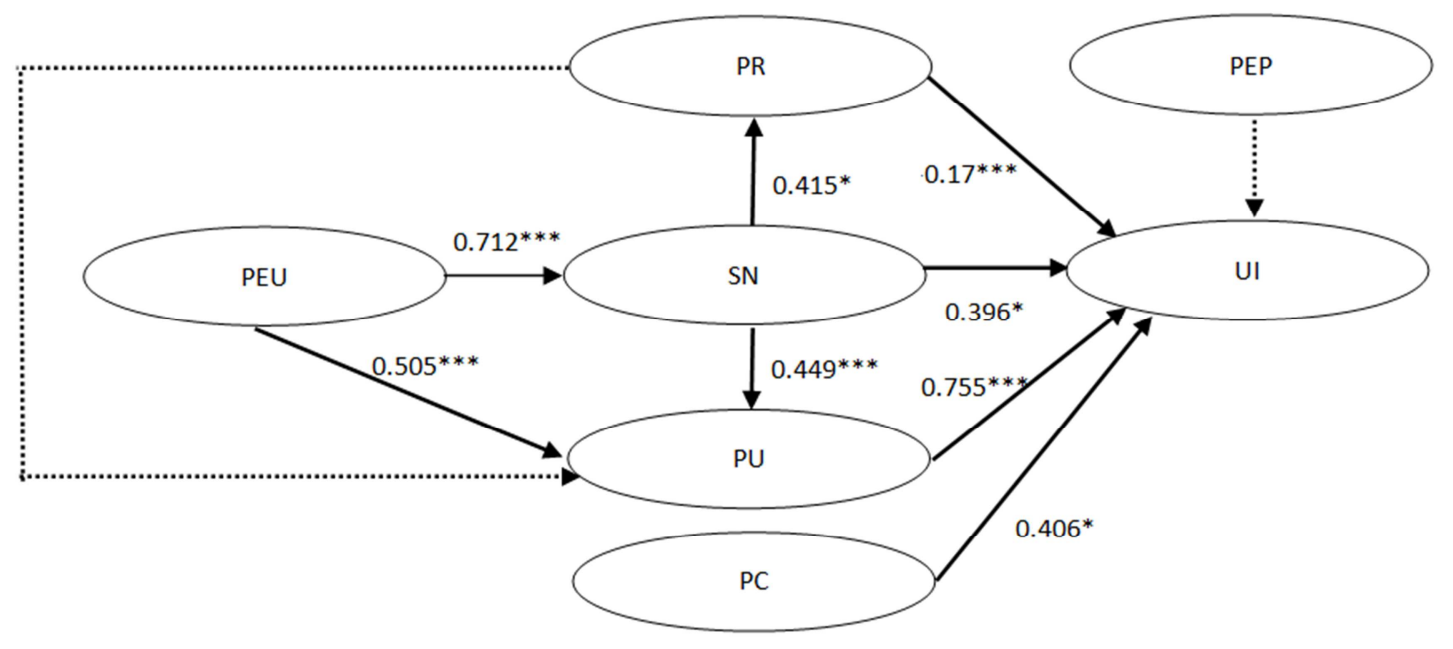

Fig. 2. The results of hypothesis testing.

\section{Conclusion, Suggestions and Limitations}

\subsection{Conclusion}

Using structural equation model, this paper examined the six factors that affect mobile banking users' intention, and found that perceived usefulness and perceived risk are the most important influence factors of mobile banking users' intention. Perceived usefulness has the most significant positive impact on users' intention. This shows that our users more care about mobile banking services, thus mobile banking system developers should pay attention to the development of practical function of mobile banking; Perceived risk has a significant negative impact on using intention. Therefore enhancing mobile banking system security and reducing the perceived risk are very necessary. This software not only requires the security of the system itself, but also must strengthen our country rights and interests protection legislation for the mobile users to ensure privacy is inviolable and let users use safely. Perceived cost is also an important factor of users' intention, and decreasing the cost of users should be considered as one of the important factors when a bank develops users. In addition, subjective norms not only have a direct impact but also an indirect effect on users' intention. Therefore, users' recommendation and external publicity play an important role in mobile banking development activities. From the empirical results, it was found that the perception of equipment performance is not the main factors that influence the mobile banking users' intention; it is the opposite of our hypothesis. Here we provide an explanation: the current smart phones and mobile network can completely meet the needs of technical conditions, mobile banking users perception level mainly has no difference, namely the user will ignore these factors when deciding whether to use mobile banking services and pay more attention to mobile banking service experience and benefits. It still needs our further study and confirmation.

\subsection{Management Suggestion and Limitation}

Based on the results of the analysis above, this paper puts forward three Suggestions for mobile banking development 
and management.

Banks manager must focus on the user's individual demand and strengthen mobile banking users' usefulness perception. Banks give full consideration to consumption habits and ways of thinking segment customer base, to provide different levels of banking services, in order to gain more mobile banking users, to increase mobile banking service function module at the same time, to improve the performance of cell phone through cooperation with mobile service provider, to reduce the users' cost.

Manager should firstly emphasize the safety of the software system in the development of software. Mobile phone banks should establish a complete system of guarantee and reduce the risk of mobile banking users' perception level. Mobile banking at the same time also needs the support of a good legal environment to protect the rights and interests of users. Relevant government departments, on one hand, should establish a related standard system of mobile banking, on the other hand, should perfect relevant mobile banking law system as soon as possible.
Marketing manager also should enhance the promotion of mobile banking and add new user experience activities. Mobile banking should take advantage of network marketing channel and the new media propaganda way to emphasize the ease of use, usefulness, and security of the mobile banking, to give full play to the positive role of users' subjective norms.

In the process of theoretical deduction and empirical research, this paper tries to pursue rigor, but because of many factors, the research also exist shortcomings. First of all, based on the limitation of time and money, sample selection area is narrower; Second, the research model does not take into account the user characteristic variables adjustment effect; In the end, it does not take into account factors such as bank brand property and operator service level. So in the further study in the future, I strive to expand the scope of the samples, to consider the level of one's education and the nature of the work. Samples such as control variable should be taken into account.

\section{Appendix}

Item scale

\begin{tabular}{|c|c|c|}
\hline Name of factors & Reference & Item \\
\hline \multirow{3}{*}{ SN } & \multirow{4}{*}{ Miu E N nb [20] } & 1-1 My relatives and friends think it is a good thing to use mobile banking \\
\hline & & 1-2 Media information made me feel using mobile banking is a very good thing \\
\hline & & 1-3The marketing activities of Mobile operators make me feel using mobile banking is a good thing \\
\hline \multirow{3}{*}{ PU } & & 2-1 I think using mobile banking made me become more efficient \\
\hline & \multirow[t]{2}{*}{ Lopez-Nicols [6] } & 2-2 I think use mobile banking could make me conduct financial transactions efficiently \\
\hline & & 2-3 I think mobile banking is very useful \\
\hline \multirow{3}{*}{ PEU } & \multirow{3}{*}{ LIU Z H [10] } & 3-1 I think I'll take the new technology esaily \\
\hline & & 3-2 I will maste rthe mobile banking skills easily \\
\hline & & 3-3 I believe that mobile banking easier than other service channels \\
\hline \multirow{3}{*}{ PEP } & \multirow{6}{*}{$\begin{array}{l}\text { Gefen [21] } \\
\text { Pavlou [12] }\end{array}$} & 4-1 I think my mobile phone support to use of mobile banking \\
\hline & & 4-2 My mobile or wireless network support to use of mobile banking \\
\hline & & 4-3 The quality of mobile phone or network affects my using of mobile banking \\
\hline \multirow{3}{*}{ PR } & & 5-1 I'm worried about the using of mobile phones bank will reveal my privacy \\
\hline & & 5-2 I worry about using mobile banking will affect my property \\
\hline & & 5-3 I think using mobile banking is safe. \\
\hline \multirow{3}{*}{$\mathrm{PC}$} & \multirow{3}{*}{ Luarn, P\& Lin, H [22] } & 6-1 I think mobile banking communications fee is higher \\
\hline & & 6-2 I think mobile banking service fee is higher \\
\hline & & 6-3 If there is a preferential policy I will use mobile banking frequently \\
\hline \multirow{3}{*}{ UI } & \multirow{3}{*}{ Taylor, S \& Todd, P [23] } & 7-1 I will continue to use mobile banking \\
\hline & & 7-2 I'll use more service of mobile banking \\
\hline & & 7-3 I will recommend my friends and colleagues to use mobile banking Later. \\
\hline
\end{tabular}

\section{Acknowledgment}

We would like to anonymous referees for helpful comments and suggestions. Also financial support by the comprehensive reform project of Beijing municipal universities to promote the talent training-innovation project for graduate student (No.XN108) is gratefully acknowledged.

\section{References}

[1] Iresearch.2014 China mobile banking user survey report [OL]. [2014-09-30]. http://www.iresearch.com.cn/Repott/.

[2] Davis, F.D. A Technology Acceptance Model for Empirically
Testing New End-user Information Systems: Theory and Results, Cambridge, MA, MIT Sloan School of Management, 1986.

[3] NAMBO C. The moderating effects of psychological reactance and product involvement on online shopping recommendation mechanisms based on a causal map. Electronic Commerce Research and Applications, 2010, (9): 522-536.

[4] KLEIJNEN M. et al. Consumer Acceptance of Wireless Finance, Journal of Financial Services Marketing, 2004, 8(3): 206-217.

[5] AJZEN I. The theory of planned behavior. Organizational Behavior \& Human Decision Processes, 1991, 50(2): 179-211.

[6] LOFEZ - NICOLAS C, MOLINA - CASTILlO F J. An assessment of advanced mobile services acceptance: Contributions from TAM and diffusion theory models. Information Management, 2008, 45(6): 359-364. 
[7] Zhong X N. The site features and individual consumer characteristics affect the network shopping. Hangzhou: Zhejiang University, 2005.

[8] Hsu C L, Lu H P. Why do people play on-line games? An extended TAM with social influence and flow experience, Information Management, 2004(41): 853-868.

[9] Guo X H. The influence factors of mobile bank user adoption research [J]. Nankai Business Review, 2009, 12(3): 12-19.

[10] LIU Z H, MIN Q F, JI S B. An empirical study on mobile banking adoption: The role of trust [A]. Proceedings of the Second International Symposium on electronic commerce and security (ISECS 2009)[C]. Nanchang, China, May 2009: 657-663.

[11] Cheng H. The empirical research of individual differences and consumers to accept online shopping. Hangzhou: Zhejiang University, 2003.

[12] PAVLOU Y A. Consumer acceptance of electronic commerce: Integrating trust and risk with the technology acceptance model .International Journal of Electronic Commerce, 2003, 7(3): 101-134.

[13] WEI T T, Marthandan G, Chong A Y, Ooi K B, Arumugam S. What drives Malaysian m-commerce adoption? An empirical analysis, Industrial Management \& Data Systems, 2009, (109): 370-388.

[14] Kleijnen, M. et al. Consumer Acceptance of Wireless Finance. Journal of Financial Services Marketing, 2004, 8(3): 206-217.

[15] DAI H, PALVIA P. Factors affecting mobile commerce adoption: a cross-cultural study in China and the United States.
The DATA BASE for Advances in Information Systems, 2008, (40): 43-61.

[16] Zhang Q J. The impact factor analysis of users accept mobile business and its application research. Hangzhou: Zhejiang University of Technology, 2005.

[17] KAPPOS A, RIVARD S. A three-perspective model of culture, information systems, and their development and use.MIS Quarterly, 2008, 32(3): 601-634.

[18] Luo P. SPSS for Windows statistical analysis. Beijing: Electronic Industry Press, 2005.

[19] VENKATESH V, MORRIS M G. Why Don`t Men Ever Stop to Ask for Directions? Gender, Social Influence, and Their Role in Tech acceptance and Usage Behavior. MIS Quarterly, 2000, 24(1): 115-239.

[20] Miu E N. The thinking of the development of mobile banking. Financial electronic, 2007, (7): 70-71.

[21] GEFEN D. KARAHANNA E. STRAUB D W. Trust and TAM in online shopping: An integrated mode. MIS Quarterly, 2003, 27(1): 51-90.

[22] LUARN P, LIN H. Toward an Understanding of the Behavioral Intention to Use Mobile Banking.Computers in Human Behavior, 2005, (21): 873-891.

[23] TAYLOR S, TODD P. Understanding Information Technology Usage: A Test of Competing Models. Information Systems Research, 1995, 6(2): 144-177. 